\title{
The Role of Women's Creativity and Innovations in the Nigerian Informal Sector of Oke Ogun Zone
}

\author{
Oluwatoyin Dorcas Alese (PhD) \\ Department of Arts Education \\ Adekunle Ajasin University, Akungba Akoko, Ondo State, Nigeria \\ Tel: 234-803-466-2266_E-mail: alesht2@gmail.com \\ c/o Dr. M A Hassan \\ P O Box 1060, Osogbo, Osun State, Nigeria
}

Received: June 3, 2011 Accepted: June 30, 2011 doi:10.5539/ies.v4n3p213

\begin{abstract}
This study was guided by the desire to advance whether concerted effort could enhance the creativity and innovations of women towards empowerment. Other purposes include: establishing the level of empowerment towards attaining good growth in building the informal sector economy and enhancing the status of women in Oke Ogun zone of Nigeria; determining the problems facing the creative abilities of women in improving their knowledge and skills through training. This study adopted descriptive survey design of ex-post facto type. Proportionate and simple random sampling techniques were used to select 128 women entrepreneurs as participants from four (4) purposively selected skills. Women Creativity and Innovations for Empowerment Questionnaire with reliability co-efficient of 0.86 was used as the main instrument to elicit responses from participants while 4 Focus Group Discussion sessions (FGDs) complemented the Questionnaire. The study indicated that there is a significant combined effect of women's socio-empowerment and women's economic empowerment on women's creativity and innovations $\left(\mathrm{F}(2,111)=3.349 ; \mathrm{R}=239, \mathrm{R}^{2}=.057\right.$, Adj. $\left.\mathrm{R}^{2}=0.040 ; \mathrm{P}=0.05\right)$. However, the Nigerian government is yet to advance a committed political will towards enhancing the efforts of women through the creation of good supportive measures, and an enabling environment to reduce poverty, create job opportunities and develop her human resources. It is recommended that the Nigerian government should demonstrate a good political will in poverty alleviation programmes, women's social groups and business organizations should be geared towards pulling labour and resources together to maximize labour productivity, information and social network which will lead to good growth of the informal sector.
\end{abstract}

Keywords: Creativity and innovations, Women empowerment, Nigerian informal sector

\section{Introduction}

The importance of economic integration of the people in a nation cannot be overemphasized especially, women who have been under appreciated for a long time in developing economies. Women play essential and dynamic roles in economic life, they adapt easily to change and are very creative. As agents of development in all societies women play tremendous roles through creativity and innovations both in the formal and informal sector although, highly prevalent in the informal sector.

Creativity and innovations have unique connotations and are thus not synonymous but are dependent on each other. Creativity is a mental and individual phenomenon involving the ability of individuals or groups of individuals in cooperation while innovations is an activity that transforms visionary ideas of creativity into products and services that deliver greater value (Rigie and Harmeyer, 2009). Amabile (1986) averred that the more the intrinsic motivation of individuals, the greater their creative output. Therefore, without creativity there cannot be new products, new models or design where women are very active.

Women constitute about half the world's total population, producing and marketing sixty to eighty percent of food (Manuh, 1998). Women are intrinsically endowed with entrepreneurial skills where creativity and innovations are key factors however, trained women form an insignificant percentage of the total skilled force in developing countries such as Nigeria. This is due to non-exposition of women to formal education early enough. This resulted in high level of female illiteracy. Women lack adequate skills and limited coverage in quality of agricultural extension 
services in processing, preserving and packaging of food (Sherief, 2008). A major reason for wastages in agricultural products during harvest, low pricing and inadequate supply throughout the year.

The endogenous creative abilities of women are also evident in crafts and handwork like beads making, tie and dye, dress making, pottery and the like. Aribisala (2000) noted that women have been involved in cottage and other micro-economic enterprise in Africa and Nigeria since time immemorial. The informal sector activities are a heterogeneous mix, encompassing and constituting a significant segment of the Nigerian economy (Wright, 1991 and Odekunle, 2000). The Nigerian informal sector is fast growing, according to Kester and Ogunyinka (2007) it absorbs $30 \%$ of the working population in the country and can be regarded as a 'safety-net' for low income workers without regular employment or social security. This accounts for the reason of the high representation of women in the sector.

The promotion and protection of the informal sector dates back to the industrial revolution and colonial development of large-scale industry but declined with the widespread optimism about modernization in the 1950s and 1960s. The interest was revived in the 1970s and was thus promoted internationally by the 1990s for stimulating economic growth, poverty reduction and empowerment (Mayoux, 2001).

Poverty reduction training programmes are carried out in developing economies including Nigeria but, are hindered by several factors which include lack of adequate skill, weak infrastructure leading to labour burden, access to finance, access to market, weak business organization, bad leadership, corruption, and insufficient technology transfer. These factors pose a big threat to an enabling environment for women's creativity in micro and small business in the informal sector and subsequently hinder the growth potential of the individual and the economic status of the society at large.

Four growth drivers had been identified as essential to wealth creation and competitiveness; these are entrepreneurship, knowledge building and knowledge sharing, ICT and human resources (National Agency for Enterprise and Construction, 2004). Nigeria is promoting a private driven economy through her home grown NEEDS (Akpobasah, 2004). Economic integration promotes cultural, social, political and inclusion in wider society, if creativity in entrepreneurship had been declared a significant driver in the future development of societal welfare, one is tempted to ask if Nigeria is serious about reducing the $70 \%$ level of poverty among her citizenry?

The illiteracy level in Nigeria is still very high of which females are more affected Adelabu and Adepoju (2007), they lack adequate skills and replicate "traditional female skills" for which the market is saturated (Mayoux, 2001 and Sherief, 2008). Production is very low because of inadequate supply of energy and technology. Economic policies does not favour creativity and innovations as governments refuse to boost the entrepreneurial activities of the informal sector through political will in provision of finance, information and good market opportunities that serves as gains of risk-taking in enterprises.

It is imperative to note at this juncture that, the inability of women to increase their potentials as large scale producers and entrepreneurs impede the creative abilities of women, growth of the informal sector and economic growth in general. Gender stereotypes affect women in the Nigerian society till date. Women lack the capital and power in the market to increase their potentials. The same activities performed by men are rated higher and attract higher remuneration. For instance, male designers and chefs are better remunerated than female designers and caterers in the informal sector. Women who have access to finance either from families and the society that promote creativity do not operate at the subsistence level like their un-empowered counterparts.

Creativity and innovations are salient factors in women's empowerment as their participation in them enhances the development of the society at large. It is however, imperative to tap and develop the creative and innovative abilities of women in the country by meeting the needs of the market with prompt action and political will to allow desired improvement in the informal sector which will enhance economic growth of the country. Consequently, this paper aims at accessing how creativity and innovations could enhance women's empowerment in the Nigerian informal sector. Research was based on four towns namely Igboho, Iseyin, Kisi and Saki, all in Oyo State, Nigeria.

\subsection{Statement of the Problem}

Creativity and innovations are key factors in entrepreneurship which women have been engaged in since time immemorial, they often come in the form of skill acquisition whereby trainees acquire the skills inherent in the family or from skillful people around them.

The process of creativity and innovations depend on each other greatly because it is the mental and visionary ideas in which simple technology of innovations assist in giving value to products for market purposes. In this case, creativity and innovations enhance the socio-economic status of countries. One cannot but conclude that creativity and innovations are quite advantageous to the nation. 
However, as creative as women are especially, their representation in the informal sector they have not been able to impact significantly on the Nigerian economy. Although, there are government intervention programmes towards poverty reduction and job creation, they do not seem to entrench women's creativity, where creative skills are developed, the sustenance in enhancing and motivating the skills are limited. Hence, this paper sought to investigate how creativity and innovations could be used to integrate women economically thereby, enhancing other integration.

\subsection{Research Questions}

i What roles does creativity and innovations have to play in women's empowerment in the informal sector?

ii How far has the women's empowerment programme assisted in enhancing the growth of the informal sector?

iii What are the problems facing the creative and innovative abilities of women?

\section{Literature Review}

\subsection{Concept and Types of Empowerment}

The term empowerment has become popular in the field of development. It has virtually replaced terms such as welfare, upliftment and poverty alleviation to describe development and intervention goals. The term empowerment has also been used with regards to assisting vulnerable groups, marginalized and subordinated members of society in which women are prevalent. People are so confused at times about empowerment as it relates to social, economic and political terms. However, it is held as panacea for social ills, high population growth rate, and environmental degradation, enhancing the status of women, poverty alleviation and the like.

Empowerment entails enabling people to understand the reality of their environment, reflect on the factors shaping that environment and taking steps to effect changes to improve the situation. It is a process that encompasses people deciding where they are now, where they want to go, and developing and implementing plans to reach their goals. Both the concept and theory of empowerment indicate the intricacies of social, economic and political empowerment of the people.

\subsection{Social Empowerment}

This proceeds by forming collectives and engages in development activities and tackle social problems. It also employs an "entry point" strategy. It uses specific activities which could be literacy class, health programmes, entrepreneurship training or capacity building to mobilize people into groups. It could be used to tackle sources of subordination. The groups determine their priorities themselves. The goal is for the groups to be independent of the initiation. The Better Life for Women Programme of the Babangida regime in Nigeria operated majorly on women cooperatives through skill development and credit facilities to enhance the productivity of women. Equally, SEWA of India recognizes the effect of social cohesion.

\subsection{Economic Empowerment}

It is an approach that attributes people's subordination to lack of economic power. It focuses on improving control over material resources and strengthening economic security. Groups are formed, organizing savings, credit facilities and training activities. Training and skill development, new technologies or marketing fall under this category. The skill development and entrepreneurial training given to people by target programmes like the National Directorate of Employment, the National Poverty Eradication Programme in Nigeria, all fall under this.

\subsection{Political Empowerment}

Politics lead to governance and decision-making. One can influence or be part of the decision-making process when one is involved. Since empowerment involves participation in an enabling environment, political empowerment is necessary where it is discovered that people or particular groups of people, sex, caste or tribe shy away from such. A good case in point is in Africa which is dominated by Patriarchy. Men see themselves as those who should be in decision-making authorities. It is very necessary to give civic or community education to create awareness that there is the dawn of a new era where women themselves should shun trepidation and participate meaningfully in affairs that affect their lives. Men alike who shy from power need to be sensitized towards the importance of participating in decisions.

\subsection{Women Empowerment}

The concept of women empowerment is the outcome of critiques and debates generated by women movement throughout the world and the Third World Feminist.

Women empowerment is entrusted with the goal of challenging patriarchal ideology, to transform structures and institution that reinforce and perpetuate gender discrimination and social inequality, to enable poor women gain access to and control of both material and informational resources. In this wise the process of empowerment must 
address all relevant structures and sources of power. The causes of women's inferior status is rooted in history, religion, culture, the psychology of the self, in laws and legal systems, and in political institution and social attitudes. Solution must penetrate all inadequacies if the status and material condition of women's life will effect a change (Schuler and Kadirgramar - Rajasingham, 1992, as quoted by Mbacham, 2001).

With the above explanation, empowerment implies an increase of consciousness, more than a forced change of power in which there was a destruction of previous structures and values. The element of higher consciousness and consideration of both parties' needs and interest gained from a win. Empowerment is both intrinsic and extrinsic. The empowerment of women does not disempower men, it further enhances their empowerment and liberation.

\subsection{Creativity and Innovations among Women}

Creativity and innovations among women are best determined through identification of creativity traits. Guilford (1962) as quoted by Bayode (2005) identified creative traits as fluency, flexibility, originality, ability to inform meanings and ability to elaborate. Meanwhile, Mckellar (1957) supported the originality in creativity when he asserted that it is the fusing of perceptions in a new way. Newness, freshness, novelty, inventiveness, all of which are acclaimed quality of originality universally.

In a similar vein, Chambers (1969) as cited by Bayode (2005) opined that creative traits is a process in which new and unique products emerge from the interaction of the organism and its environment, involving the dimensions of level field and type. Innovations transform the visionary ideas of creativity into practical products, service or processes that deliver greater value. The result of which can be incremental, evolutionary or radical in its impact on the status quo.

The analysis above implies that both creativity and innovations are dependent on each other. It is impossible to develop a truly innovative organization if creativity is ignored. In the same vein, without effective process in place to transform creative ideas into practical, real world, value added application, creativity cannot attain commercial value (Rigie and Harmeyer, 2009). Women internationally, including Nigeria are very creative they have a history of combining both creativity and innovations to effect positive changes in the society. Former President Babangida asserts that Nigerian women have a history of engaging in productive activities on the farm and in the various cottage industries across the country (Guardian Newspaper, April 28, 1992).

In a similar perspective, Aribisala (2000) submits that apart from trading, a high percentage of women are engaged in activities like food processing, shoemaking, textile, tailoring and weaving of the informal sector. The creative and innovative abilities of women can be seen in the entrepreneurial skills they possess. They bring out various meals as finished products from agricultural products like yam flour, cassava flour, palm oil, smoked fish and the like. Adire from textile, beads, pottery to mention a few. Originality and uniqueness can also be found in mixtures and pattern of dress making, hat making, catering services, hair dressing, computing to mention a few. Innovation and creativity are keys to success in industries where women are prevalent.

\section{Methodology}

The study adopted the descriptive survey research design which enhanced the collection of data from a sample of women from a selected entrepreneurial skills programme: Interior Decoration, Fashion Designing, Computer Analysis and Hairdressing. The choice of these skills was based on the fact that they are prevalent among women.

The participants for the study were one hundred and twenty-eight (128) women. They were drawn on equal basis of 32 participants each from the 4 purposively selected skills using the stratified and simple random sampling techniques. Their ages range from 18 years to 45 years. Out of the 128 participants $102(79.7 \%)$ are married, 16 $(12.5 \%)$ are not married while $10(7.8 \%)$ are widowed. The participants literacy rate range from the Basic education to the Junior Secondary level. They farm and process food for the family at the subsistence level. The duration of the entrepreneurial skill was six months.

The study was delimited to Oorelope Local Government Area centre in Igboho, Oyo State. The choice of Igboho centre for the conduct of the study was based on the fact that Igboho centre is the only one covering the whole of Oke Ogun area which is densely populated and has the potential of imparting entrepreneurial skills as a secondary occupation to the well known "food basket" of Oyo State which could help enhance better development of the people. A twenty-five item self-developed structured questionnaire tagged "Creativity and Innovations for Women Empowerment Scale" with a reliability coefficient of 0.86 was used as the main instrument to elicit responses from respondents. Out of a total of 128 questionnaires administered to the respondents, 120 were returned while only 114 $(89.06 \%)$ were well filled and adequate for data processing.

The 114 well-filled questionnaires formed the basis of data analysis for the study. The Focus Group Discussion (FGD) was equally used to capture information that may have been omitted by the researcher or avoided by the 
respondents in writing. A total of 4 Focus Group Discussion sessions were conducted with the participants from the 4 entrepreneurial skills selected; this makes one session each for the skills. During the FGD sessions, notes were taken by the researcher.

\subsection{Discussion of Findings}

The result of the study indicates that there is a significant combined effect of women's socio-empowerment and women's economic empowerment on women's creativity and innovations $\left(\mathrm{F}(2,111)=3.349 ; \mathrm{R}^{2}=.057, \mathrm{Adj}^{2} \mathrm{R}^{2}=\right.$ 0.040; $\mathrm{P}<0.05$. This confirmed previous studies Wright (1991) and Manuh (1998); Aribisala and Odekunle (2000); Mayoux (2001); and Kester and Ogunyinka (2007), the study reveal that women's creativity and innovations has the potential of empowering women as well as providing growth for the informal sector and economic growth for the nation. These findings were corroborated by the efficient data generated through the Focus Group Discussions. For instance, the Interior Decoration FGD session agree that:

Creativity and innovations in women is worthwhile. You know our tradition that we don't run after men, it is men who run after us, our time is well utilized by equipping ourselves in things like this that will give us money to take good care of our families and children. We do not want our children to suffer like us. We want them to be big people living in towns like you to compensate for our sufferings.

\section{Interior Decoration FGD/Igboho (August $6^{\text {th }}$ 2008)}

The Fashion Designing FGD Group said:

A, e wa gbo nkan, idi ise eni la moni lolee, lati igba aye awon iya wa lobirin ti nise tie, won o sise titi bi akura, won tun fi n sin awon Baba wa ti se oko won nigbana sugbon, ori obirin ti pe ni sin. Ti a ba sise, a fi n ran awon omo wa nile iwe giga, a si ri ninu wa to ti kole. Moto nikan laatii ronu re nitori awon ona wa ti ko dara wonyi ati awon ole to n yo wa lenu.

(Fashion Designing FGD/Igboho August 6 $\left.{ }^{\text {th }}, 2010\right)$

\section{Meaning:}

Ah! Hear her, hard work pays, women have been well engaged and hardworking since time immemorial but they used their gains to worship their husbands then, these days we send our children to higher schools and build houses with proceeds of our creativity though we are not thinking of cars now because of our bad roads and robbers.

\section{Fashion Designing FGD/Igboho (August 6th, 2010)}

\section{Again, the Hairdressing unit reports that:}

You know this our work is our great Grand mother's work. Our mothers are fashionable in their own way then, though, it does not yield much for them then but, now if you know what you are doing, our business is good. People weave, plait and dress like one thousand Naira worth of hair these days, The only problem is that we are not very close to big urban centres where there are many university students and better supply of energy and materials of production.

\section{Hairdressing FGD/Igboho (August 6 ${ }^{\text {th }}, 2010$ )}

Another Group of discussants said:

Computer analysis training is very good if you know it very well ma, you will not want to do monthly jobs again for example, the printers cannot print on their papers without us. We must help them analyse and design. Those people don't joke with us and we charge them accordingly. Even some people who are working like you come to us for apprenticeship training.

\section{Computer Analysts FGD/Igboho (August 6 ${ }^{\text {th }}, 2010$ )}

The above is an indication that women's creativity and innovations have the potential of empowering women since they are endogenous although, most women engage in "traditional female skills" in which the market is saturated. This also accounts for women's high illiteracy rate which limits the types of skills that women can engage in. This agrees with Adelabu and Adepoju (2007), Sherief (2008) and Mayoux (2001) positions that there is high level of illiteracy in women which hinders increasing their potentials and that women entrepreneurs in the informal sector in developing countries are engaged mostly in "traditional female skills" for which the market is saturated. This view was corroborated at the Hairdressing FGD session: 
You will agree with us that you were lucky to be sent to school as a girl. Most of us here were not that lucky, we always watch what our mothers and neighbourhood women do which later translate into additional income for us today apart from going to farms with our parents and husbands.

Hairdressing FGD/Saki (August $13^{\text {th }}, 2010$ )

Again, the Fashion Designing session said:

Most of us went to primary school and after, we were rushed into marriage but later learnt tailoring/fashion designing. We were lucky to have skills training like the Better Life and NAPEP otherwise we would have been sewing torned pants and clothes, your know our tradition believes so much in men and that they, know how to do things better than women.

Fashion Designing FGD/Saki (August 13 ${ }^{\text {th }}$, 2010)

Yet, the Interior Decorating FGD unit submits

The introduction of free secondary school education enabled us to be a little better off than most of our colleagues. Interior decorating business has to do with churches, offices, engagements of people of class and taste and sometimes you look for them in bigger cities where you can purchase your materials of production and sell your services.

\section{Interior Decoration FGD/Saki (August 13 ${ }^{\text {th }}, 2010$ )}

The Computer Analysis session further reiterates that:

He! If you are not well lettered, you cannot come to this section because you need the skills of literacy to be competent and deliver your services well in computer analysing.

\section{Computer Analysis FGD/Saki (August13th, 2010)}

Despite this, without mincing words women's creativity and innovations assist in mopping up the under utilized labour pool among women which is also gaining government attention.

In line with Odekunle (2000) most of the respondents agreed that it is better to enter the informal sector easily and find something doing rather than being idle. However, previous studies submit that there is the need for the government to pay more attention on the integration and funding of the informal sector through the provision of finance and necessary infrastructure to enhance women's creativity. This is also in line with the submission of Odekunle (2000) and Sherief (2008).

Supporting this, the discussants have this to say:

Without money and necessary infrastructure nothing can be done easily. Take for instance, our case here. We wanted sets of computer to enhance our business, we had to save and save for months and years before buying them. After this, the Power Holding Company too brings electricity when they like. Saving for generator too is another burden, no good road, potable water and good market for our services. To live in this country is not easy o.

\section{Computer Analysts FGD/Iseyin (September $6^{\text {th }}, 2010$ )}

Again, the Hairdressing unit reiterates that:

It is only God who can save us from these leaders. They promised us heaven and earth before we voted for them yet, we have not seen their impact. Without good supply of electricity, our business cannot grow. They are also not doing anything to borrow us money to buy generators.

\section{Hairdressing FGD/Iseyin (September $6^{\text {th }}, 2010$ )}

Yet, the Interior Decorating discussants said:

You see, interior decorating and fashion designing go hand in hand. There are several styles and types of decoration that we were supposed to learn and teach our apprentices which non-constant supply of electricity did not allow. Our roads are bad. To get to Ibadan and Lagos to buy our materials for production is also difficult. No one is helping us.

\section{Interior Decoration FGD/Iseyin (September $6^{\text {th }}, 2010$ )}

Furthermore, the Fashion Designing unit has this to say: 
Ee sebi kori o sa jowo da ni sibi ire ni. A gbo pe iwe tawa ka ko to jeun lode oni a sit un $n$ gbiyanju komo wa ma ba seru aye leyin wa ola, ki won o si ma ba doko, Baba ni Baba gbogbo aye. Nigbati atelewo wa tun wa fe maa tan wa je $n$ ko, latari wipe ko si iranlowo kankan lati le ra irinse ati ta awon nkan oja wa nko. Be ba si bijoba, won ni awon kan ni n kowo ti won ni ki won o ya wa je, too Olorun $n$ be o.

Fashion Designing FGD/Iseyin (September $6^{\text {th }}, 2010$ )

\section{Meaning:}

May we be fortunate, we are not literate enough to work in offices but we are striving to empower our children so that they will not engage in prostitution or be slaves in future but our efforts are futile because there is no assistance to enable us sell our products. We learnt that the money allotted to us was embezzled, well God lives.

\section{Fashion Designing FGD/Iseyin (September $4^{\text {th }}, 2010$ )}

The above confirm the submission of Odekunle (2000); Mayoux (2001); Olajide (2004) and Sherief (2008) that it is highly pertinent to give financial aids and create an enabling environment for women's creativity in developing countries to enable it impact positively on economic growth of nations. This is evident in the findings of the study.

The relative effect of each independent variable show that women's socio-empowerment contributed $(\boldsymbol{\beta}=.239, \mathrm{P}$ $<.05)$ and women's economic empowerment contributed $(\boldsymbol{\beta}=.022, \mathrm{P}>.05)$ respectively. This indicates that while women's social empowerment was significant, women's economic empowerment was not. This is not unconnected with the fact stated above that several factors which include inadequate supply of finance, infrastructure, technology, market and leadership style in developing countries serve as impediment towards a good atmosphere for breeding women's creativity and innovations for a significant growth in the economy of such countries. This further agrees with Manuh (1998) and Emeagwali (2006) that:

Unless Africa significantly increases its intellectual capital, the continent will remain irrelevant in the $21^{\text {st }}$ century and beyond. Africa needs innovators, producers of knowledge and wise men and women who can discover, propose, and then implement progressive ideas. Africa's fate lies in the hands of Africans and the solution to poverty must come from its people. The future that lies ahead of Africa is for Africa to create, after the people have outlined their vision. (Emeagwali, 2006 p. 12)

Based on this, women's creativity and innovations in developing countries including Nigeria is labour intensive though associated with some elements of socialization. The study therefore, agrees with Manuh (1998); Mayoux (2001); and Sherief (2008) that the low development of roads and transportation affect both male and female entrepreneurs. Women who live in communities with low infrastructure are worse affected. Studies have shown how women's time is affected by inadequate transport systems.

Women spend more than 700 hours a day fetching water in Ghana, 500 hours in Tanzania and 200 hours in Zambia. Collecting fuel-wood is a predominantly female responsibility in most African countries.

(Calvo, 1994 as cited by Sherief, 2008 p.3)

How do creativity and innovations thrive in a situation like this? Furthermore, the Hairdressing Focus Group discussants confirmed this:

Ha! We cannot do anything without water in our business. As you can see, we need to wash customers hair, heat water also for their use apart from our own domestic use. But if you have apprentices, they go and collect firewood and water for cooking and washing of towels.

Hairdressing FGD/Kisi (September $21^{\text {st }}$, 2010)

Similarly, the Fashion Designing session said:

Iya mo n je obirin gidi mo ni, afi ki Olorun pin wa lere, ko si je a jeere awon omo wa. Nigbati a ba wa ounje ninu ile tan pelu igidana ti a rin meli aimoye ka to ri ni ao tun wa ponmi ti a ofi se, ki a to raye ti ibise wa, ti yoo fun wa lowo lati toju ile ati awon omo wa. Awon NEPA na tun $n$ se tiwon. Monsinni olowo lafi $n$ ranso dipo ti o nina eletriki, aayonu eledu la $n$ lo pelu ti ko ba ti si ina ijoba.

Fashion Designing FGD/Kisi (September $21^{\text {st }}$, 2010)

\section{Meaning:}


Only God can reward women for their labour. After taking care of the home front with sessions of fetching water and collection of fuel wood, it is equally very tiring to get money from our business. Electricity is not always there and we result to using coal iron and manual machines to provide our services.

Fashion Designing FGD/Kisi (September $21^{\text {st }}$, 2010)

Again, the Interior Decorating unit has this to say:

Doing business here is very difficult. You know that women here cannot share domestic roles with their husbands, yet our business are affected because of lack of amenities like electricity, good market to buy our products because of the distance from big cities. We have to iron our materials before decorating them too. Some of us farm, do this business and still sell provisions to make ends meet.

\section{Interior Decorators FGD/Kisi (September 21 ${ }^{\text {st }}$, 2010)}

The Computer Analysts further explained that:

You cannot compare cities with stable electricity, good roads, potable water and information units with ours. Many a time servers are down and there is little you can do with that. Although we are eating but things would have been better than this if business had been good.

\section{Computer Analysts FGD/Kisi (September 21 $\left.{ }^{\text {st }}, 2010\right)$}

\section{Recommendations}

It is clear from the study that creativity and innovations are a good pair for enhancing development in a nation, they also have the potential for creating job opportunities and stimulating economic growth in the informal sector which is expanding presently, and where women predominate. However, not only is the poverty level in Nigeria high; the potentials of women's creativity and innovations had been weakened to a subsistence level because of lack of a good atmosphere and supportive measures for breeding creativity and innovations in the informal sector. This has therefore, weakened the level of contribution of a sizeable percentage of the population of women in the sector to economic development.

However, the heterogeneous mix of the informal sector, the high representation of women in the sector coupled with the endogenous creative abilities of women is enough reasons for the government to harness the growth and development potentials. The government needs to take active role in supporting women's creativity and innovations through the provision of necessary infrastructures, functional education, and micro-financing by well coordinating and monitoring efforts in order to rid corruption from the institutions that provide economic support for such programmes. This researcher is of the opinion that a good provision of an enabling environment geared towards political will, on the part of the policy makers will go a long way to boosting women's creativity and innovations without being labour burdened.

It is expected that the government will assist in providing good market and information to women to enhance their creative and innovative abilities. Where there is good market and price for products, the motivation is always there for creativity as no one wants to offer services at an unproductive costs.

The government should encourage expansion of women's creativity and the informal sector while leading a competitive and export - oriented stride through the consumption of the products and a tax relief for exported goods. Through this, cottage industries will expand and women will produce at a higher level rather than the subsistence stage they have engaged in since time immemorial.

It is the candid opinion of the researcher that women's social groups and business organizations should be geared towards pulling labour and resources together. These will go a long way to maximizing labour productivity, information and social network.

\section{Conclusion}

With all this revelations, no doubt women's creativity and innovations can enhance the desired growth and development of the Nigerian economy but it would be noted that the opportunity to tap women's creative and innovative abilities was not well placed. Although, there are target programmes for such through skill development, these had not been well planned, implemented and monitored.

It is high time the government put in place measures to eliminate target poverty reduction programmes turning into white elephants through serving as conduit pipes for wealth accumulation by some unscrupulous elements.

The target audience or beneficiaries should be involved in programmes that will affect them right from conception. 
It is imperative to say that women still need to be well integrated in the society in developing countries such as Nigeria without which the nation cannot attain development. Paramount to the findings and in line with Manuh (1998) and Caldwell (2006) submissions, the study therefore, conclude that rather than giving new training or duplicating efforts without the necessary supportive measures and a good enabling environment for enlargement by beneficiaries including women, the already existing programmes could be boosted through political will and well coordinated and monitored efforts by all stakeholders to ascertain a high level of accessibility and utilization among women which will not be as labour burdened as it is now.

Small businesses generate uncertain income which only has a marginal effect on the integration of the owners. Most women in developing countries do business in unfavourable environment because of the low starting capital. However, such businesses are physically and mentally demanding while profitability is low.

\section{References}

Adelabu, M.A., \& Adepoju, T.L. (2007). Women and Higher Education. Implication for Sustainable Development. A Paper presented at the second Regional Conference on Reform and Revitalization in Higher Education Organised by Higher Education Research and Policy Network (HERDNET) at the International Institute for Tropical Agriculture (IITA) Ibadan 13-16 August, 2007.

Akpobasah. M. (2004). Developing Strategy/or Nigeria. A Paper Presented A-at a 2 - day Seminar Organized by the Overseas Development Institute London 1617 (June, 2004).

[Online] Available: http://66.102.9104/searchPq=cache:pMqgu9ix67kk.J: www.odi.orguk/speechcs/Nigeria_2004/Akopobash\%2520paper\%2520web.Pdf+national+economic+development+ strategy + in + Nigeria\&hi $=$ en\&ct=cln\&sd=1 (June 4, 2009)

Babangida, M. (1992). In Mrs. Babangida Offer Solution to Women Under Development. "The Daily Sketch”. Oct. $1: 3$.

Caldwell, Z.T. (2006). Closing Gender Gaps: Why it Matters.

[Online] Available: http://us.oneworld.net/article/view/127481/1/ (May 25,2007)

Emeagwali, P. (2006) Ideas, Not Money, Alleviate Poverty in our social Development for Poverty Reduction mhtml:file://E:/titi.mht (October 21, 2009).

[Online ] Available: http//www.ideamarketere.com/? Innovation \& article id-600592 (August 3, 2009).

Kester, K.O., \& Ogunyinka, K.O. (2007). Broadening Labour Relations Beyond the Formal Sector: The Challenges of the Informal Sector in Nigeria Ife Psychologia 15 U, 1-11

Manuh, T. (1998). Women in Africa's Development Overtaking Obstacles, Pushing for Progress.
Africa
Recovery
Briefing
Paper
(1).
(2008).
[Online]
Available:

http://www.on.org/ecosoides/geninifo/afrec/bpaper/maining.htm (May 25, 2008)

Mayoux, L. (2001). Collective Strategies Reconsidered: Social Capital, Women's Empowerment and Sustainability in West Africa. Micro-Finance Programme, NGOs in a Global Future. University of Birminham.

Mbacham, P.T. (2001). Women Empowerment and Poverty Alleviation for Sustainable Development: A Comparative Study of COWAD-Nigeria and VOCADER - Cameroon MED Thesis Department of Adult Education University of Ibadan. Ibadan pp163

Odekunle, S.O. (2000). Skills Acquisition as a Determinant of Entrepreneurship Success in Nigeria A Case Study of Ikirun Informal Sector NISER Monograph Series 12.

Rigie, \& Harmeyer. (2009). Clearing up the Confusion about Creativity and Innovation.

[Online] Available: http//www.ideamarketers.com/?innovation\&articleid=600592-Cached-Similar (August 3, 2009)

Wright, E.H. (1991). Training Opportunities in the Informal Sector of Freetown in Sierra Leone. A Research Study in Supplement to Adult Education and Development 37/1991 DVV. 
Table 1. There will be no significant joint and relative effect of women's socio-empowerment and women's economic empowerment of Women's Creativity and Innovation.

\begin{tabular}{|c|c|c|c|c|c|c|c|c|}
\hline Variables & F-Ratio & Sig. of $\mathrm{P}$ & $\mathrm{R}$ & $\mathrm{R}^{2}$ & Adj. $\mathrm{R}^{2}$ & $\mathrm{~B}$ & $\mathrm{t}$ & $\mathrm{P}$ \\
\hline $\begin{array}{c}\text { Women's Socio-empowerment } \\
\begin{array}{c}\text { Women's economic } \\
\text { empowerment }\end{array}\end{array}$ & 3.349 & .039 & .239 & .057 & .040 & .022 & .022 & .983 \\
\hline
\end{tabular}

It was shown in the table above that there is significant joint/combined effect of women's socio-empowerment and women's economic empowerment on Women's Creativity and Innovation $(F(2,111)=3.349 ; \mathrm{R}=.239, \mathrm{R} 2=.057$, Adj. $\mathrm{R} 2=0.040 ; \mathrm{P}<.05$ ). About $6 \%$ of the variation was accounted for by the independent variables while the remaining $94 \%$ was due to other unused factors.

The relative effects of each independent variable showed that women's socio-empowerment contributed $(\beta=.022)$, $\mathrm{P}>.05$ ) respectively indicating that while women's socio-empowerment was significant, women's economic empowerment was not in the study.

Table 2. Focus Group Discussion Schedule of the Study

\begin{tabular}{|c|c|c|c|c|}
\hline Skills & Location of FCD & $\begin{array}{c}\text { Number of } \\
\text { sessions }\end{array}$ & Date & $\begin{array}{c}\text { No. of Members } \\
\text { per session }\end{array}$ \\
\hline Computer & Igboho & 1 & August $6^{\text {th }} 2010$ & $8-10$ \\
\hline Hairdressing & Saki & 1 & August $3^{\text {rd }} 2010$ & $8-10$ \\
\hline Fashion designing & Iseyin & 1 & September $6^{\text {th }} 2010$ & $8-10$ \\
\hline Interior Decoration & Kisi & 1 & September $21^{\text {st }} 2010$ & $8-10$ \\
\hline
\end{tabular}

Source: Field Survey 2010.

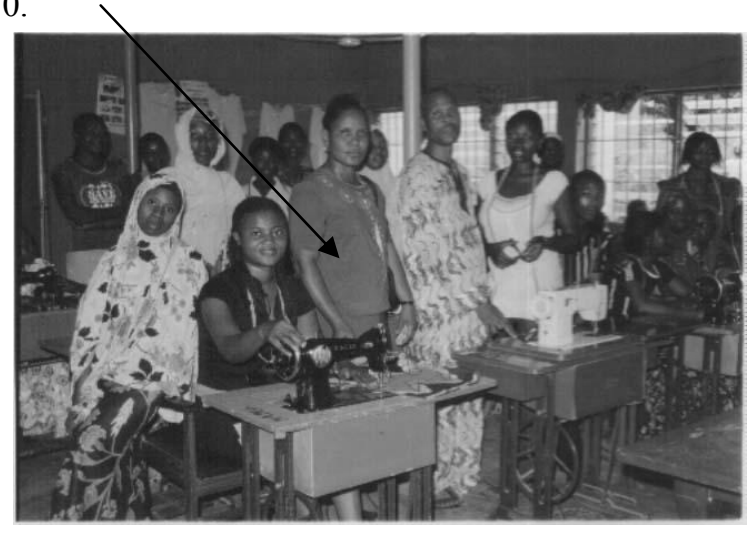

Researcher, Instructor and some of the Trainees during a Practical Class of Fashion Designing Skill Development

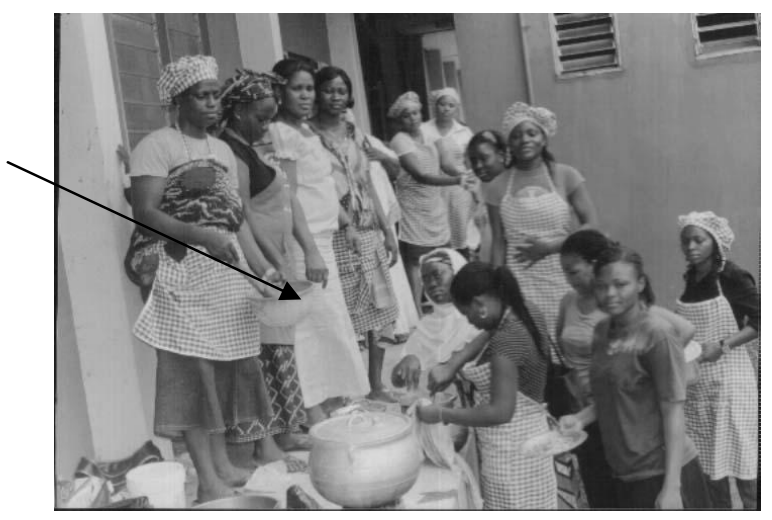

Researcher, Instructors and some Beneficiaries Preparing for Graduation Party 


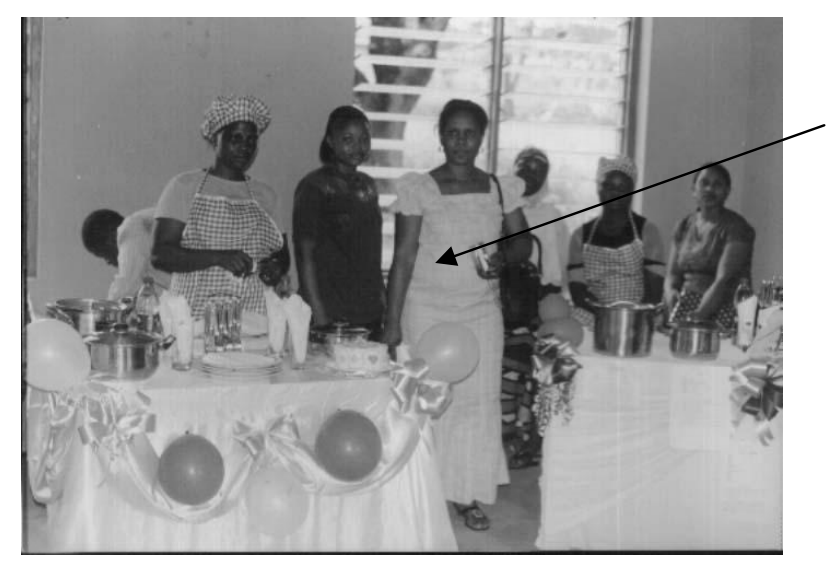

Researcher with some Beneficiaries during Graduation

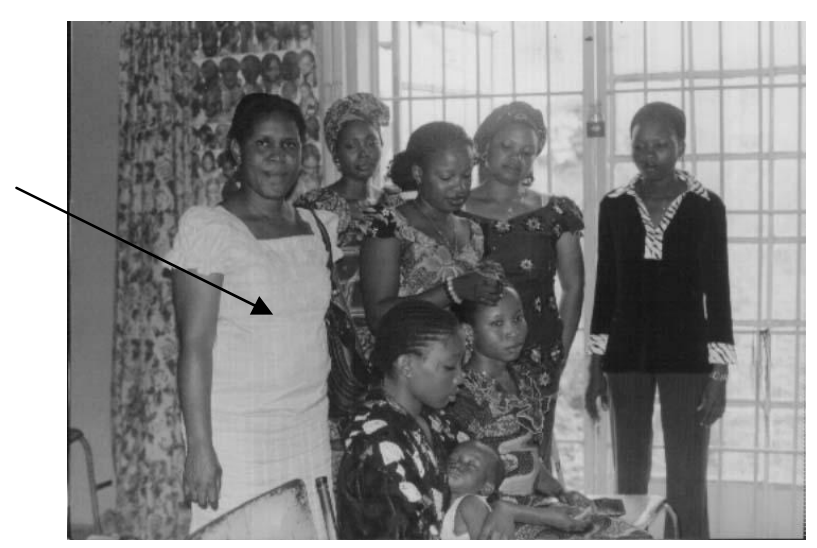

Researcher, Instructor and Trainees during a Practical Class of Hairdressing Skill Development

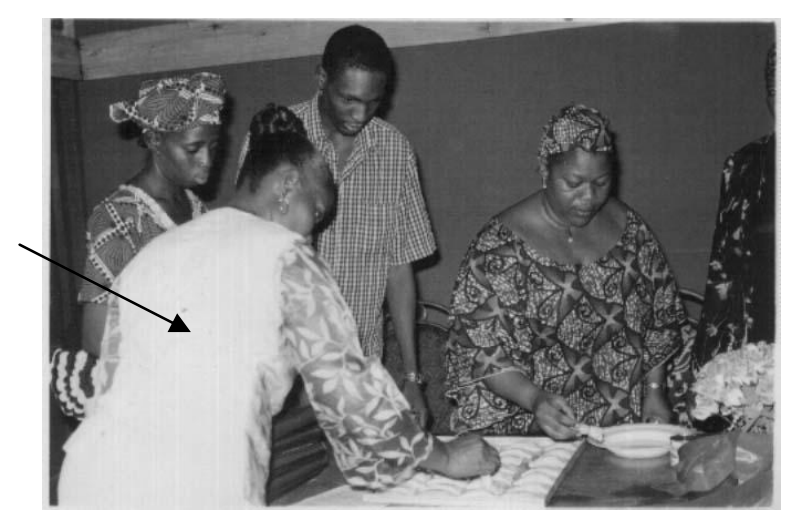

Researcher and Instructors Preparing for a Social meeting 